www.jmscr.igmpublication.org

Impact Factor 3.79

Index Copernicus Value: 5.88

ISSN (e)-2347-176x ISSN (p) 2455-0450

crossref DOI: _http://dx.doi.org/10.18535/jmscr/v4i02.38

Journal Of Medical Science And Clinical Research

IGM Publication

An Official Publication of IGM Publication

\title{
Madness In Self Injury-Severe Cut Throat Self Inflicted Injury By A Mentally Deranged Person
}

\author{
Authors \\ Mohammad Mojahid Anwar', Mohd Asrarul Haque ${ }^{2}$, Faiz Ahmad ${ }^{3}$, \\ Munawwar Husain ${ }^{4}$, Jawed Ahmad Usmani ${ }^{5}$, Mohd Adil ${ }^{6}$ \\ ${ }^{1 \& 3}$ Junior Resident, ${ }^{2}$ Senior Resident, ${ }^{4}$ Professor, ${ }^{5}$ Professor \& Chairman, \\ Department of Forensic Medicine, J. N. Medical College, AMU, Aligarh 202002 \\ ${ }^{6}$ Senior Resident, Department of Dermatology, JNMCH, AMU, Aligarh 202002 \\ Corresponding Author \\ Dr Mohd Asrarul Haque
}

Senior Resident, Dept of Forensic Medicine, J. N. Medical College, AMU, Aligarh 202002.

E-mail: asrar428@gmail.com

\begin{abstract}
There are innumerable cases in which mentally deranged individual have attempted self inflicted injury over the neck and throat. This injury is glaringly absurd in nature and could defy logic and reasoning. The present case report is on in series of such cases. The uniqueness in the present case is that mentally unsound person practically severed his neck under the command of a voice considered by him holy and binding.

Key-words: Self-inflicted injury, mentally deranged, cut-throat, psychiatric disorder, Command from spirit.
\end{abstract}

\section{CASE-HISTORY}

Mr X, 30 years old, married, was brought to the causality section of JNMC Aligarh, accompanied by his wife in the month of July 2015, in a critical condition requiring immediate emergency measure. He was provided the required medical treatment at the emergency section and was kept under observation for two days. Once his condition stabilised he was shifted to the surgical ward for additional treatment and recuperation.

\section{HISTORY}

\section{Personal and Past History}

The patient was of average built and illiterate. The history was provided by the attendant accompanying the patient because he was incommunicado. It appears that he was hearing voices since the past several months. These voices were commanding in nature, forceful and instrumental in enforcing the individual to submit himself to its dictate. Most of the time family members recognised his condition and did not leave him alone. Therefore, he was prevented in principal from doing any damaging act by the constant vigil provided by the relatives. However, in this particular occasion he was left unattended and therefore, he got the opportunity to self destruct. Basically this is against the nature and objective of forensic psychiatry. Clinical studies have demonstrated that such people at risk should not be left with razor $^{1,2}$ sharp instrument ${ }^{3}$ or appliance $^{4}$ that could facilitate hanging. In fact 
anti-ligature $^{5}$ appliances are used to the best availability.

\section{Family History}

No significant finding was elicited pertaining to the psychiatric illness favouring his schizophrenic, manic depressive psychosis, delusion and paranoid tendency. The family members were unable to provide the treatment card from a psychiatrist or the treating doctor indicating that he was suffering from a recognized psychiatric illness.

PHYSICAL EXAMMINATION (At the time of admission)

Vitals: BP: 110/76 mm of $\mathrm{Hg}$.

PR: 96/min regular. RR: 18/min.

Temp: $98.6^{\circ} \mathrm{F}$.

\section{NECK}

a. An incised wound running from one lateral most side of the neck to the other side.

b. Depth 3 inches and gaping.

c. Margins clean cut, no bruising or foreign body was detected within the injured area.

d. Slight bleeding persisted, indicating that injury was fresh and approximately of two hours duration.

e. Trachea was partially cut.

f. The patient was calm and non panicky.

g. The neck was firmly covered and pressed by the relatives with multiple layers of cloth to stop bleeding.

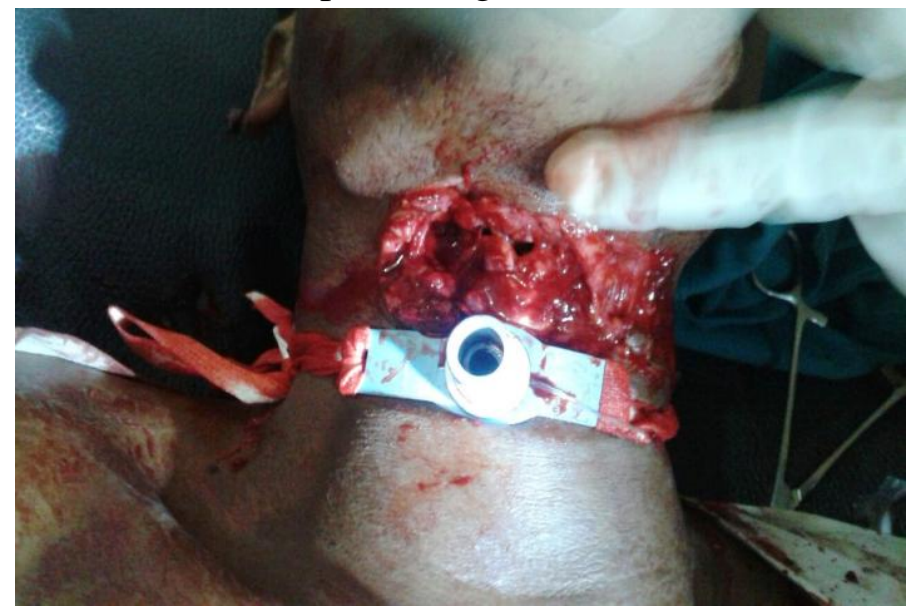

Fig. 1: Tracheostomy tube in situ which has been inserted in the opening of the wound.

\section{DISCUSSION \& CONCLUSION}

Mentally challenged individuals particularly those suffering from schizophrenia, manic depressive psychosis (MDP), and of delusional propensity are known to indulge self inflicted injury $6,7,8,9,10$. There are instances in which person attempted suicide by cutting neck by scissor, ${ }^{11}$ sickle, ${ }^{12}$ table saw, ${ }^{13}$, sword,${ }^{14}$ sharp spike, ${ }^{15}$ fencing guard,${ }^{16}$ and occasionally by pliers ${ }^{17}$ and pincer. ${ }^{18}$

The present case doesn't fall into the grisly act because the weapon used was sharp-edged knife and not other weapon mentioned above. Nevertheless the nature and dimension of injury speaks volubly about the influence of unknown an unseen voice.

\section{REFERENCES}

1. Rautji R, Behera C, Kulshrestha P, Agnihotri A, Bhardwaj DN, Dogra TD. An unusual suicide with a safety razor blade-a case report. For Sci Int., 2004; May 28; 142(1): 33-5.

2. Shrabana RK, Devinder AK, Atul M, Yashoda R. Cut throat injury by vehicular accident. I J Med Specialties, 2012; 3(1): 94-97.

3. Joshi SS, Jagade M, Nichalani S, Bage S, Agarwal S, Pangam N: Technicality of Managing Cut Throat Injury. Int $\mathrm{J}$ Otolaryngology Head Neck Surg, 2013; 2: 11-12

4. Johnson E. Selecting custom torque prescriptions for the straight-wire appliance American Journal of Orthodontics and Dentofacial Orthopedics , 143(4), S161 S167

5. K.E. Kõlves, D.M. Skerrett, K. Kõlves, D. De Leo. SUICIDERESEARCH: SELECTED READINGS Volume 7 November 2011-April 2012. Australian Institute for Suicide Research and Prevention. WHO Collaborating Centre for Research and Training in Suicide Prevention. National Centre of Excellence in Suicide Prevention. Griffith University. 
6. Keeney BT, Heide KM. Serial Murder: A more accurate and Inclusive Definition. Inter J Offender Therapy and Comparative Criminology, 39(4), 1995.

7. Lohner, J., \& Konrad, N. (2006). Deliberate self-harm and suicide attempt in custody: distinguishing features in male inmates' self-injurious behavior. International Journal of Law and Psychiatry, 29(5): 370-385.

8. Rao KN, G Bharathi, Chate S. Genital self-mutilation in depression: a case report. Indian Journal of Psychiatry, 2002,44(3): 297-300.

9. Bhat PS, Pardal PK, Diwakar M. Selfharm by severe glossal injury in schizophrenia. Ind Psychiatry J 2011; 20: 134-5.

10. Mokros, A., Osterheider, M., Hucker, S.J., \& Nitscke, J. (2011) "Psychopathy and sexual sadism." Law \& Human Behavior, 35(3), 188-199

11. Cox WA.. Sharp edged and pointed instrument injuries. Accessed at on February 3, 2015: https://forensicmd.files.wordpress.com/20 11/07/sharp-edged-and-pointedinstrument-injuries1.pdf

12. Shetty BKS, Padubidri JR, Bhandarkar AM, Shetty AJ, Shetty M. "Atypical suicidal" cut throat injury- a case report. J For Legal Med., 2009; 16: 492-493.

13. Hejna $P$. Unusual suicide using a table saw. For Sci Med Path., 2013; 9 (3): 446448

14. Shrabana RK, Devinder AK, Atul M, Yashoda R. Cut throat injury by vehicular accident. I J Med Specialties, 2012; 3(1): 94-97

15. Berman J, Wallace P H. Cutting and the Pedagogy of Self-disclosure. Univ of Massachusetts Press. 2007. ISBN 978155849.

https://books.google.co.in/url?client=ca- print-university_massachusetts_ press $\&$ format $=$ googleprint $\&$ num $=0 \& i d=P t$ IB0rrUVGsC\&q=http://www.umass.edu/u mpress/fall_07/berman.htm\&usg=AFQjC NF9mlmg8aqviJSM4G_PoRbbLBPlaw\&s ource $=$ gbs_buy_r

16. Sofsky W. The Order of Terror: The Concentration Camp. Princeton University Press. 1997. https://books.google.co.in/books?id=ClmQ 8PPjF44C\&pg $=\mathrm{PA} 57 \& \mathrm{lpg}=\mathrm{PA} 57 \& \mathrm{dq}=\mathrm{FE}$ NCING+GUARD+USED+IN+SUICIDAL + ATTEMPT\&source $=$ bl\&ots $=$ PxpO8gskq $1 \& \operatorname{sig}=\mathrm{qX}-\mathrm{AH}-$ rjJ2YAXafwMUkJsWqX8O4\&hl=en\&sa= X\&ved=0CC4Q6AEwA2oVChMIm6jLtaj uxwIVFgWOCh3XJgDb\#v=onepage $\& \mathrm{q}=\mathrm{F}$ ENCING\%20GUARD\%20USED\%20IN $\%$ 20SUICIDAL\%20ATTEMPT\&f=false

17. James Ellroy. Suicide Hill. Random House.

https://books.google.co.in/books?id=jjGeLDdsR4C \& printsec $=$ frontcover $\# \mathrm{v}=$ on epage \&q\&f=false

18. KIR MZ, Gündüz E , Güllü MN, Uysal C, Korkmaz M, İçer M, Zengin Y, Gürbüz H - Recurrent Suicide Attempt Cases in Diyarbakir, Turkey. Eur J Forensic Sci. (2014), [cited September 10, 2015]; 1(1): 9-12. doi:10.5455/ejfs.165199 